\title{
布の湿感限界水分率に関する一考察
}

\author{
長崎大学教育学部 鈴 木 淖
}

\section{A STUDY ON THE CRITICAL WATER CONTENT OBTAINED BY SENSARY TEST OF MOIST FABRICS}

\author{
By Atsushi Suzuki
}

(Department of Home Economics, Faculty of Educations, Nagasaki University, Nagasaki)

There is a close relation between damp or oppressive sense and water content of fabrics. The differences in the critical water content of damp sense of fabrics among fibers have been suggested as one of major factor when we discuss comfortable use of fabrics. The relation between the subjective rating of critical water content of damp sense and the experimental results of fabrics was mainly discussed in this paper.

That is to say, results of sensary test of four kinds of knit fabrics, polyester, acrylics, wool and cotton, on damp and oppressive sense were compared with those measured by both the sliding resistance of water sorbed fabrics to a metal, from which the clingy forces were assessed, and the changes of the temperature and the heat flow in drying. The relationship were mainly investigated between the critical water content of damp sense, the effects of water content to the clingy forces and the temperature or the heat flow. It was found that the critical water content of damp sense was characterized by the critical water content where the clingy force showed the remarkable increase, and the so called the second critical water content in the falling-rate period of drying.

(Received August 31, 1981)

\section{1.はじめに}

着用時において，衣料湿った感し(湿感)やそれに基 つく抵抗感(密着感)があることは非常に不快なものであ る。との湿感ないしは密着感は䋊維の種類によってかな り晎なることが指摘されり，高温多湿の気候条件下や運 動時にあっては極机て直接的な問題であり，衣料の基礎 的性質の一つとして重要 ${ }^{2}$ である。従来，水分阔每する 着でてちの研究 ${ }^{9}$ は数多くあるが，最近の絒維の種類に よる布の「湿感限界水分率 ${ }^{1)} 」 の$ 研究は興味克る問題で ある。しかし，乙の湿感限界水分率について，物理量亡 の対応で提えた直接的な研究は余り見当らないようであ る。

そこで，本報告ではこの湿感ないしは密着感の問題を 布の皮虐への自然接触を想定した低荷重領域に打ける布 の接触問題として捉え，それに関係する物理量として， つぎの二項目を取り上げ検討した。すなわ占，試料とし て、ポリエステル，アクリル，木綿，羊毛の各メリヤス
肌着を例にとり，一つは吸水布(等温吸湿曲線の範囲に ある)のすべり抵抗を測定するととにより，いわいる颣 着説 ${ }^{4)}$ に基づく布の密着力を導出し，いま一つは熱板に 接触させた吸水布（水を過飽和汇湿潤させた）の乾燥過程 に枋ける温度ならびに熱流量の変化特性を測定した。る してそれらの結果の対水分率特性を俨価し，湿感ないし は密着感の官能試験に上る結果，特に湿感限界水分率に ついて比較したので報告する。

\section{2. 実験}

\section{1 試 料}

表 1 に用いた試料の諸元を示した。試料は䋐維種別に よる市販のメりヤス肌着で，使用に際し精練処理し，標 準状態に謂整して用いた。

繊維種別は親，柾水性の違いを吸湿性とぬ㣗易さの観 点からとらえ，ポリエステルでは吸湿性が小さくぬれに くいもの，アクリルでは吸湿性が小さくぬれ易いもの， 羊毛では吸湿性が大きくれれくいもの，木綿では吸湿 
Table 1 Details of samples.

\begin{tabular}{|c|c|c|c|c|c|c|c|c|c|c|c|}
\hline Samples & $\begin{array}{l}\text { Number } \\
\text { of yarns } \\
\text { (n/cm) }\end{array}$ & $\begin{array}{l}\text { Count } \\
\text { (d or } \\
\text { s) }\end{array}$ & $\begin{array}{l}\text { Thickness } \\
(\mathrm{mm})\end{array}$ & $\begin{array}{l}\text { Air } \\
\text { content } \\
(\omega)\end{array}$ & $\begin{array}{l}\text { Dry } \\
\text { weight } \\
\left(\mathrm{g} / \mathrm{cm}^{2}\right)\end{array}$ & \begin{tabular}{|l|} 
Water \\
content \\
$(\%)$ \\
$(20 \mathrm{C} 65$ \\
\% R.H. $)$ \\
\end{tabular} & $\begin{array}{l}\text { Contant } \\
\text { angle } \\
(\circ)\end{array}$ & \begin{tabular}{|l|} 
Rate of \\
water \\
absorbtion \\
(mm $/ 10$ \\
min)
\end{tabular} & $\begin{array}{l}\text { Air } \\
\text { permeability } \\
\left(\mathrm{cc} / \mathrm{cm}^{2} / \mathrm{sec}\right)\end{array}$ & $\begin{array}{l}\text { Water } \\
\text { permeability } \\
(\%)\end{array}$ & $\begin{array}{l}\text { Hard- } \\
\text { ness } \\
(\mathrm{mm})\end{array}$ \\
\hline $\begin{array}{l}\text { Polyester } \\
\text { knit }\end{array}$ & $15 \times 13$ & 82.5 & 0.86 & 88.9 & 0.0132 & 0.4 & 68 & 18 & 177 & 58 & 77.5 \\
\hline $\begin{array}{l}\text { Acrylics } \\
\text { knit }\end{array}$ & $13 \times 18$ & 150 & 0.39 & 78.5 & 0.011 & 1.5 & 55 & 80 & 221 & 54 & 87.0 \\
\hline $\begin{array}{l}\text { Wool } \\
\text { knit }\end{array}$ & $13 \times 15$ & $1 / 37.5$ & 50.65 & 83.6 & 0.0157 & 14.1 & 82 & 0 & 183 & 53 & 89.0 \\
\hline $\begin{array}{l}\text { Cotton } \\
\text { knit }\end{array}$ & $13 \times 19$ & $42.5 / 1$ & 0.69 & 85.7 & 0.0153 & 7.9 & 55 & 110 & 181 & 57 & 85.5 \\
\hline
\end{tabular}

性が大さくぬれ易いものの代表しして選んだ。なお，試 料の諸兀は次の上うな湘定法に準拠し，標準状態におい て測定した檤である。まず，厚さ，通気度，風軟度等の 測定については，それぞれ織物厚さ計，フラジール型通

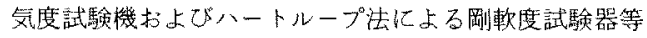
を用いて湘定した。吸水速度はバイレッ夕法による測定 值を示し，根湿率は乾燥重量に刘する水分率で示した。

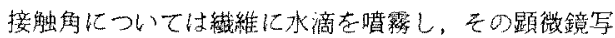

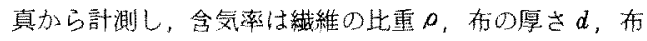
○乾燥重量 $v_{0}$ 等を知って，式 $100\left(\rho d-v_{0}\right) / \rho d$ 加計算 した。また，透湿性については，力ップ法に上り20分

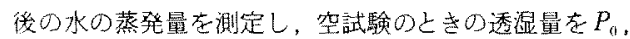
布をつけたときの透湿量を $P$ とし，式 $100\left(P_{0}-P\right) / P_{0}$ から評要した。

\section{2 物理試験}

\section{A. すべり抵抗の測定}

庭1（a）に示す上うなEulerのバルトの理諭 合の布のすへり抵抗(摩摖力) 測定した。すへり抵抗の 測定には被接触面，接触生，摩擦速度，鼬度などいるい ろな要件が問題となるが，本報告では着用条件のうち，

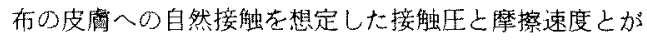
小さい場合を例により，任意な条件に上り実施した。ま た，布の水分率は等温吸湿曲線の範进に五万比較的低水 分率の場合を対黎亡した。

まず摩擦機棈には記録計の記録紙の巻き取り機構を流 用し，有の被接䖝面には巻さ取りドラムの金属面(クロム 処理による平滑面)をそのまま利用した(表面はアルコー ルと水とで洗鿇好理し，乾燥させて用いた）。このとき， 被接触面の回転半佳は $r=1.91 \mathrm{~cm}$ で, 摩擦速度は周速 $1.8 \mathrm{~cm} / \mathrm{min}$ であった。また，布の接触触は $\theta=\pi / 2$ $\operatorname{rad}$ で，試料幅は $b=2.3 \mathrm{~cm}$ とした。試料の装着に当っ ては試料の闻端を接触部分上り長く(希の垂下長は $l=$ $4.8 \mathrm{~cm})$ しり，その下端とは小さな垂下荷重 $\left(R_{0}^{\prime}=0.84 \mathrm{~g}\right.$, $1.79 \mathrm{~g}, 3.6 \mathrm{~g}, 5.91 \mathrm{~g})$ を掛けた。すべり抵抗标定格 $20 \mathrm{~g}$ のUL型ストレインゲージを用いて梚出し，すべり抵抗

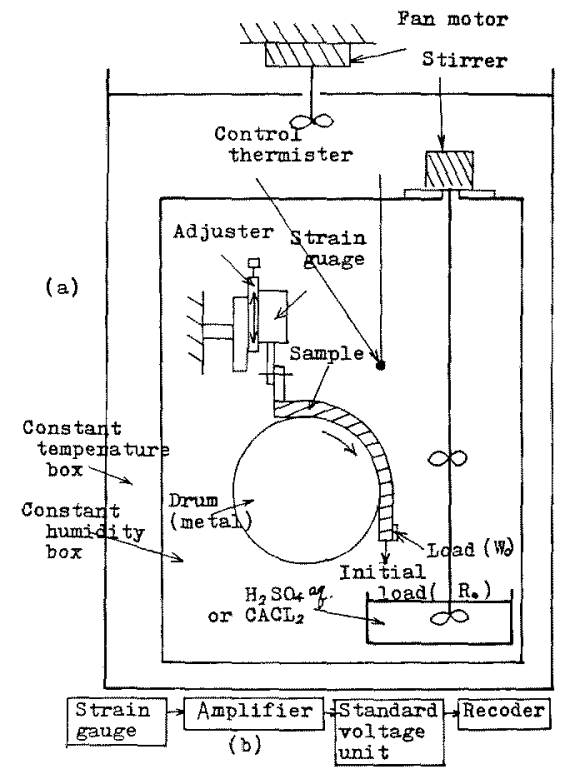

Fig. 1 Schematic diagram for measuring the sliding resistance of water absorbed fabrics.

(a) Schematic diagram of main parts of the apparatus

(b) System for recording the sliding resistance

が定常状態になったときり值を読み取った。測定渞度は $20^{\circ} \mathrm{C}$ 己，布の水分率は硫酸溶液又は粉椄状塩化力n シウムで調整（硫酸溶液および調湿ボックス内はゆっく りとかくはんした)し，その上きの水分率は測定中併置 した奇の水分率赛测して求めた。四1(b)には測定の 系統図を示した。以上の方法により布のすべり抵抗一水 分摔曲線を求め，その結果加水分率が布の密着力级及 ぼす影響について検討した。

\section{B. 温熱要化の测定}

図2 (a)に示すような一定熱鼠 $(1.5 \mathrm{~V}, 220 \mathrm{~mA})$ を供給 している熱板に水分を過飽和に湿潔させた布を接螌させ 


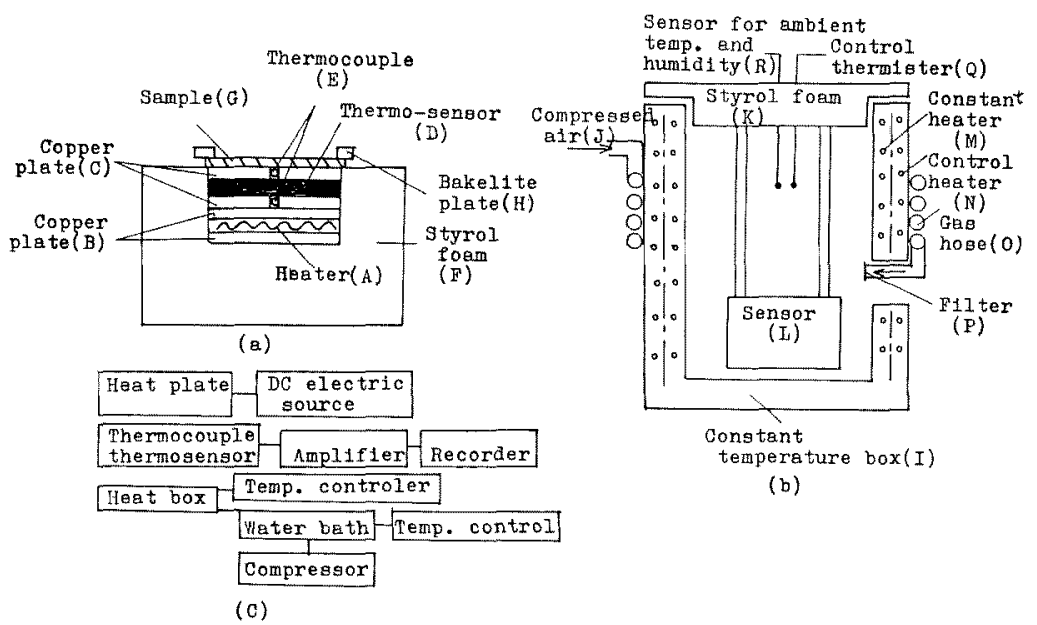

Fig. 2 Schematic diagram for measuring the changes of temperature and heat flow in the period of drying of wet fabric.

(a) and (b) Schematic diagram of main parts of the apparatus

(c) System for recording the changes of temperature and heat flow

て，その乾燥過程における温度及び熱流舅の变化特性を 测定した。ヒーターAには $2.9 \times 2.9 \mathrm{~cm}^{2}$ ，厚さ $0.1 \mathrm{~cm} 0$ 銅板 $\mathrm{B}$ をええ，その上には，上下を銅板 C (Bと同じ)て はさんだ熱流計D（放熱面が $2.9 \times 2.9 \mathrm{~cm}^{2}$ ，常温附近の熱 流特性が $80 \mathrm{kcal} / \mathrm{m}^{2} \cdot \mathrm{hr} \cdot \mathrm{mV}$ ○市販品である）をセッ卜 した。

このとき，各接触部にはシリコングリースを鉒布し， 接触の安定化を計った。銅板 Cの中央部にはクロメルー コンスタンタン熱電対 $\mathrm{E}$ (径が $0.1 \mathrm{~cm}$ 弱)を配置 (冷接点 付き) し，上唰の熱電対を湿度測定用亡し，“下側の熱䉓 対を熱流量の温度補正用の参考しした。そして，熱板の 外周を発泡スチロールで断熱し，その境界部分上熱電対 Eの配置部分とは防水の意味屯含めて，シリコン樹脂て 補修した。また，銅板Cの表面は黒体染装をはじしした。 試料 $\mathrm{G}$ の大きさは $3 \times 3 \mathrm{~cm}^{2}$ で接触は自重のみとし，試料 の外周 $0.1 \mathrm{~cm}$ 部分をべーク板 Hで押え，接螌の安定化 を計った。なお，夰を過飽和に湿潤させる方法は接触の 安定性にも役立っている。寒験環境には図2(b)に示す ような陶土で作った恒温槽 $\mathrm{I}$ (内佳 $8 \mathrm{~cm}$ ，高さ $17 \mathrm{~cm}$ ) 在 考え，槽内には水中を通過させた玨縮空気了（温度 $20^{\circ} \mathrm{C}$ ， 玏 $1 \mathrm{~kg} / \mathrm{cm}^{2}$ ，風量 $10 \mathrm{l} / \mathrm{min}$ )を循環させて湿度の安定

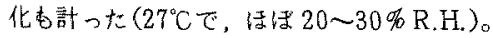

試料の装着は測定系が定常状態にあるかどうかを確䜀 した上で，槽内加らKの部分をつり上げ，挨出部L（図 2(a)《相当する)を取り出し，素早く試料を装着加つ湿 湢させて，もとの槽内に設置した。との上き一時，系の 熱バランスがくずれるが，测定期間中，槽内の温度が革
調堌減しないようとーター $\mathrm{M} と \mathrm{~N} と の$ 電圧バランスに注 意を払った。そして，出力は電在〜畤間曲線として読み とり，その徭キャリブレーションカーブにより温度お゙

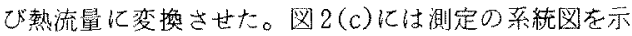
Lた。

実験は最初乾燥過程の全体について温度および熱流量 の变化を測定し，以後、乾燥過程の中途段階で測定を中 断し，その時点での乕の水分率自動天科にて夷測し，各 測定点での埧度ならび熱流最の対水分率曲線在求めた。

\section{3 官能試駼}

\section{A． 水分率を規定した布の場合}

あらかじ水方率を規定した布について次のような条 件に上る接触感の官能武験を行った。

（1）試 料: 表 1 の試料で， $1 ， 25 ， 5 ， 10 ， 20 ， 30$ ， $40,50,60 \%$ の水分率に予的吸水させた（調湿したデシ ケー夕，水の浸漬，脱水乾燥などによる) のを，P. P. フィルムに密閉し，実験室内にかなりの時間放置した後 官能試験に供した。なお，水分率汃1\%已2.5\%のものは ポリエステル試料とアクリ心試料のみとし，水分率肪 50 \%上60\%のあのは木綿試料と羊毛試料のみとした。

（2）实験環境：標準状態の不感気流下に书ける快適な 噮境で行った。

（3）被検者: 成人男子10名である。

（4）官能榙监法：簡便で接触面が比較的大きい方法上 して左存の前腕部を感賞センサーとして用いた。そのと きできるだけ客観性を持たせるために左右に取り付けた 別々の円筒状試料を一対比较により同時チェックしなが 
Table 2 Items of comfort feel and evaluated values.

\begin{tabular}{|l|l|l|l|l|l|}
\hline \multicolumn{1}{|c|}{$\begin{array}{r}\text { Evaluated } \\
\text { values }\end{array}$} & \multicolumn{1}{|c|}{1} & \multicolumn{1}{|c|}{2} & \multicolumn{1}{|c|}{4} & \multicolumn{1}{|c|}{5} \\
\hline $\begin{array}{l}\text { Moist } \\
\text { feel }\end{array}$ & Dry & $\begin{array}{l}\text { Slightly } \\
\text { moist }\end{array}$ & Moist & $\begin{array}{l}\text { Considerably } \\
\text { moist }\end{array}$ & $\begin{array}{l}\text { Very } \\
\text { moist }\end{array}$ \\
\hline $\begin{array}{l}\text { Oppressive } \\
\text { feel }\end{array}$ & Smoothy & $\begin{array}{l}\text { Slightly } \\
\text { oppressive }\end{array}$ & Oppressive & $\begin{array}{l}\text { Considerably } \\
\text { oppressive }\end{array}$ & $\begin{array}{l}\text { Very } \\
\text { oppressive }\end{array}$ \\
\hline $\begin{array}{l}\text { Warm or } \\
\text { cold } \\
\text { feel }\end{array}$ & Warm & $\begin{array}{l}\text { Slightly } \\
\text { cold }\end{array}$ & Cold & $\begin{array}{l}\text { Considerably } \\
\text { cold }\end{array}$ & $\begin{array}{l}\text { Very } \\
\text { cold }\end{array}$ \\
\hline $\begin{array}{l}\text { Comfort } \\
\text { feel }\end{array}$ & Comfort & $\begin{array}{l}\text { Slightly } \\
\text { discomfort }\end{array}$ & Discomfort & $\begin{array}{l}\text { Considerably } \\
\text { discomfort }\end{array}$ & $\begin{array}{l}\text { Very } \\
\text { discomfort }\end{array}$ \\
\hline
\end{tabular}

らそ扎ぞ机の試料の接触感を評価した。一対比較の組み 合せは繁雑さと無䭾をはふくため，水分差が20\%末淦ま でとし，整理の都合と䋊維間にも意味を持たせるために， 一つは同一繊維闰志の四つのグループ, 今一つは 2 種類 の繊維を掛け合わせた六つのグループについて行った。 としろで，以上を組み合せると 134 対の組み合せとなり， 1 人が全て行うには間題加残る。をこで，水に対する皮

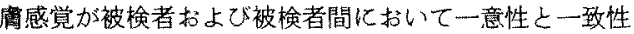
とが高いとよを根拠に被㭘者 1 人が二つのグループを受 け持つこととし，全てランダム化して実施した。

（5）評価方法：接触感の評価項目は湿感および密着感

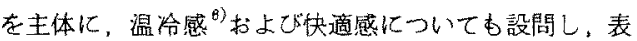
205 段留評価基本に，各評洒值の中間の評点泉許し た。そして，官能検亩の実施汇当り，表 2 の基準を「乾， 湿，ぬれ」の概念として与光，俨価值 3 から 4 は湿感に

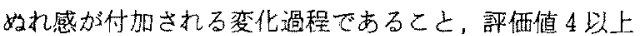
では好感がその主体となることなどの説明を加え，闻 極端な試料について最初に情報を与えるとととした。結 果は個々の評点老総平均して求めた。

\section{B．乾燥過程にある布の婸合}

温熱測定時の乾燥途中にある試料について湿感限界水 分率の測定を行った。すなわち，水分率を㬰測した後の 試料についてその都度表 2 をあとに被㭘者 3 名に上る判 定を行った。なお，測定は試料面(熱板に接触していた 面とそうでない面）にとだわるととなく試料全体から受 ける接触感を手の甲で評価した。

\section{3. 実験結果}

\section{1 物理試験の結果}

\section{A.すべり抵抗の湘定結果}

\section{1）初荷動およひ水分率の影整}

各試料の水分率 $\alpha(\%)$ が異なるときのすべり抵抗の测 定結果をすべり抵抗 $R_{1}$ 一初荷重 $R_{0}(\mathrm{~g} / 2.3 \mathrm{~cm})$ (ここで，
$R_{0}=R_{0}^{\prime}+\omega_{0}(1+\alpha / 100) b l$ で， $\omega_{0}$ は布の単位面鉷当り の乾燥重量 $\left(\mathrm{g} / \mathrm{cm}^{2}\right)$ である）曲楾として図了に示した。る の結果は本実験条件下の結果としてすべり抵抗と初荷重 とが直線関係にあり，すべり抵抗が初荷重の增加上とも に大きくなっている。また，すべり抵抗は水分率ととも に大きくなってて扔り，特に水分率の高いととろで直線の 勾配と直線を外挿した切片の值とが大きくなっている。 その一例を対水分摔曲線として見直すと図40ようにな る。すなわち，水分率がある程度大きくなるとすへり抵 抗の大きさがより潁著となる傾回にある。

\section{2）密葿力による取り扱い}

一般に瀻維素材の摩擦力(すべり抵抗)はBowdenの法

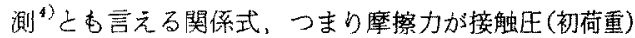
に対して指数関数しして示される。しかし，図3のよう に初荷重が限定さ扎た場合に注 Amonton やCoulombの 法則 $^{4)}$ として(1)式が成立する7)

$$
R^{\prime}=\mu^{\prime} w^{\prime}
$$

ここで， $R^{\prime}$ : 摩擦力， $\mu^{\prime}$ : 摩擦係数， $w^{\prime}$ : 接触压であ る。

この場合，布の摩擦特性は通常摩擦係数の変化として 求められるが，この摩擦係数は織維の種類や布構成に上 って影響を受ける。そとで今後，同一䄉維で布構成が翼 なる試料についても検討を進める必要が古るが(禣足夹 験に上れば，織維種別に上る特性が僙先する)，本報告 では次のような凝着説に基づく解析を試み，緘維種別に よる布の水分効果の定性的な特徴を把握してみることに した。

すなわち，図3 の直線関係はWhilehead 始まる凝着 説），つまり凝着力(密着力) $F^{\prime}$ を考えると(2)式として あ成立する。

$$
R^{\prime}=\mu^{\prime \prime} w^{\prime}+F^{\prime}
$$

ここで， $\mu^{\prime \prime}:$ 真の摩擦係数である。しかし，(2)式の 場合，接触王に無関係な真の摩擦係数亡は何加という点 

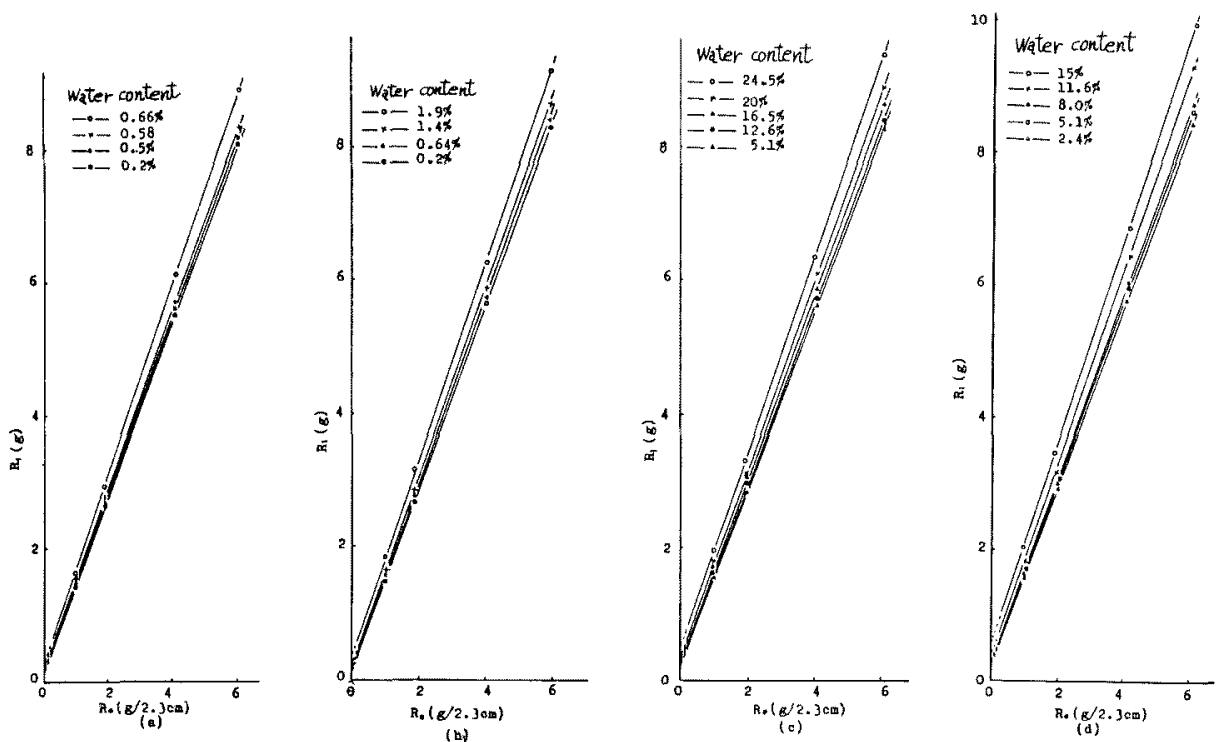

Fig. 3 Relation between the sliding resistance $R_{1}$ of the fabric which differs in water content and initial load $R_{0}$.

(a) Polyester knit, (b) Acrylics knit, (c) Wool knit, (d) Cotton knit.
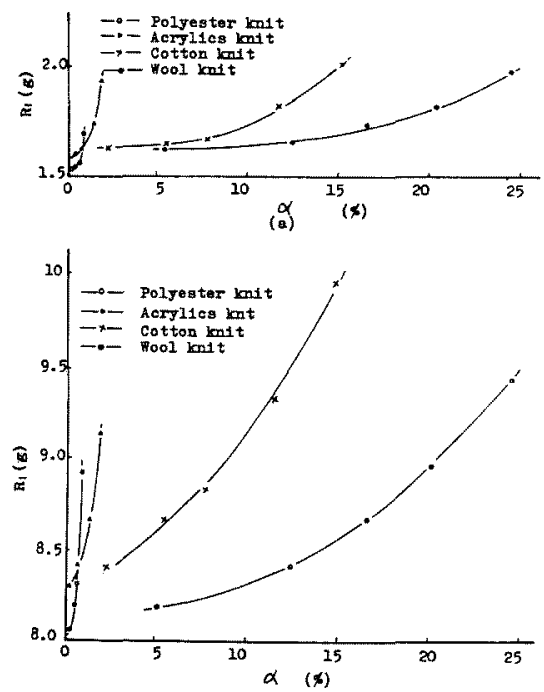

(b)

Fig. 4 Relation between sliding resistance $R_{1}$ and water content $\alpha$.
(a) $R_{0}^{\prime}=0.84 \mathrm{~g}$
(b) $R_{0}^{\prime}=5.91 \mathrm{~g}$

で蜼点が指摘されている。

そこで，図3の結果について(1)式および(2)式の変 形として，(3)式を当てはめ，䄉維種別による各試料の 特徽つけを行うことにした。

$$
R^{\prime}=\mu^{\prime \prime \prime}\left(w^{\prime}+F^{\prime \prime}\right)
$$

ここで， $\mu^{\prime \prime \prime}$ : 摩擦係数、 $F^{\prime \prime}$ : 密着力である。

いま（3）式による関倸をべルト卦け法による展開式 として，Eulerのベルトの理論 ${ }^{5)}$ によ求めると図3の すべり抵抗 $R_{1}(g)$ は (4) 式で示される（詳しくは付録に よる)。

$$
\begin{aligned}
R_{1}= & e^{\pi \mu / 2} \cdot R_{0}+b w_{0}(1+\alpha / 100)(r+d / 2)\left\{\left(1-\mu^{2}\right)\right. \\
& \left.+2 \mu e^{\pi \mu / 2}\right\} /\left(1+\mu^{2}\right)+b r\left(e^{\pi \mu / 2}-1\right) F
\end{aligned}
$$

ここで， $\mu$ : 縻擦係数， $F$ : 密着力 $\left(\mathrm{g} / \mathrm{cm}^{2}\right)$ である。

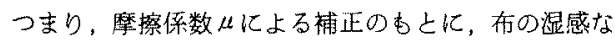
いしは密萻感に関係する物理量上して, 密着力 $F O$ 水分 率依存性を取り上げ検討した。

\section{3）密着力の水分率依存性}

すなわち，図 3 から直線の勾配怙上び切片の值を求め その結果 (4)式に当ては中 ${ }^{8)}$ ，密着力 $F$ 上摩擦係数 $\mu$

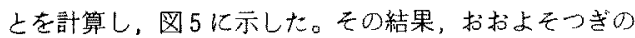
上うな特徵を得た。まず密着力 $F$ 上摩擦係数 $\mu$ 上は水分 率が高くなるとともに大きくなり，密着力ではほぼ 0.05 $\sim 0.2 \mathrm{~g} / \mathrm{cm}^{2}$ 程度の值をとり，摩摖係数でははぼ $0.2 \sim 0.3$ 程度の値を得た。つきに密着力の繊維種別に上る試料の 違いではポリエステル試料とアクリル試料の場合には水 争率加2名以下と小さいに古加からず，密着力Fの変 化が顕著で，时エステルでは水分率がほぼ 0.6\%、アク リルでは水分率がはぼ $1.2 \%$ とてろで密着力が急増す る特徴を示している。一方，木綿試料上羊毛試料の場合 


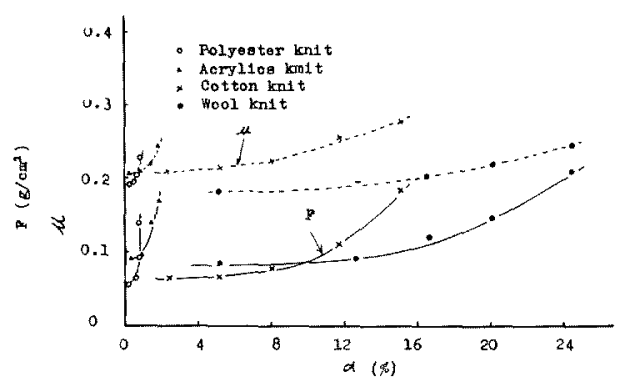

Fig. 5 Relation between "clingy force" $F$ and frictional coefficient $\mu$ of water absorbed fabric, when the initial load is in the region of about $1 \sim 6 \mathrm{~g} / 2.3 \mathrm{~cm}$, and water content $\alpha$.

には密着力 $F$ の变化が䌅慢で木綿の場合で水分率が11 名前後，羊毛の場合で水分率が 16\%前後になって始め て顕著に增大する特徽を示した。なお，ここで以上の各 水分率密着力心限界水分率 $\alpha_{F}(\%)$ 上呼ふ汇とにする。

\section{B. 温熱变化の測定結果}

吸水布の乾燥渦程における温度 $T(C)$ お方よで熱流量 $H$ $\left(\mathrm{kcal} / \mathrm{m}^{2} \mathrm{hr}\right)$ 测定結果を対水分率曲線として图 6 亿示

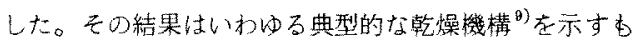
ので、つぎのような特徵が認めら机る。まず水分率があ る大きさ以上の上ころでは温度枋よで熱流量が水分率の 大きさにかか氺らずはばー定で，いわゆる恒摔乾燥期間 にあることが分る。との恒摔乾燥期間の隄界水分率在推 定してみると，扔㧍よを羊毛試料では50６0\%，木綿斌 料では 30 - $40 \%$ ，アクリ儿試料ては $20 \%$ 前後，ポリエ ステル試料では 10 前後の值䎲あるととが推察される。 その後、水分率加減少するに伴っていわ的減率幹燥 期間に入り，熱流量が小さくなり温度が上昇する。

今，図60結果を刘数関数として表加し(こで， $T_{0}$ ，

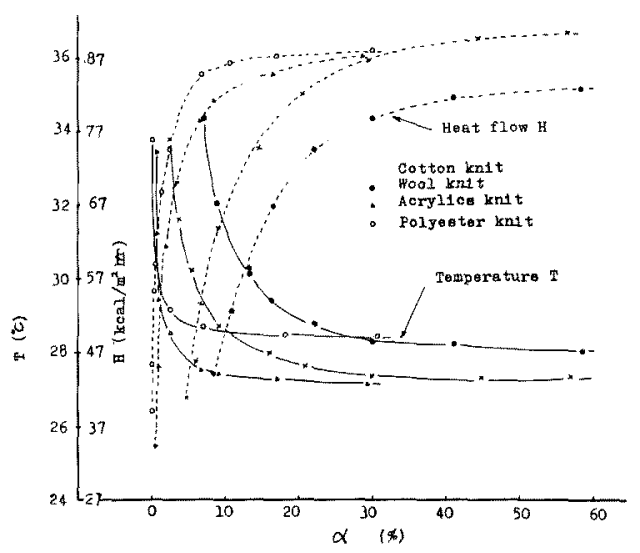

Fig. 6 Changes of temperature $T$ and heat flow $H$ versus water content $\alpha$ in drying of wet fabric.
$H_{0}$ は恒率乾燥期間の温度 $\left({ }^{\circ} \mathrm{C}\right)$ お方よび熱流量 $\left(\mathrm{kcal} / \mathrm{m}^{2} \mathrm{hr}\right)$ の值である)，図7亿示すとある水分率のところで変曲 点か認妙られる。吉なわ5，图７の水分率の高い直線領 域を減率第 1 段，水分率の低い直線領域を減率第 2 段之 して考えるとをの変曲点に打ける水分率はいわゆる第 2 限界水分率として与えられる。すなわち，その值は羊毛 試料の場合温度曲線で $\alpha_{r_{2}}=18 \%$ (熱流量曲線で $\alpha_{H_{2}}=20$ \%)，木綿試料の場合同 $9.5 \%$ (同 $13 \%$ )，アタリル試料の 場合同 $5 \%$ (同 $6 \%$ )，ポリエステル試料の場合同 $2.5 \%$ (同 $2.5 \%$ )の值を示している。

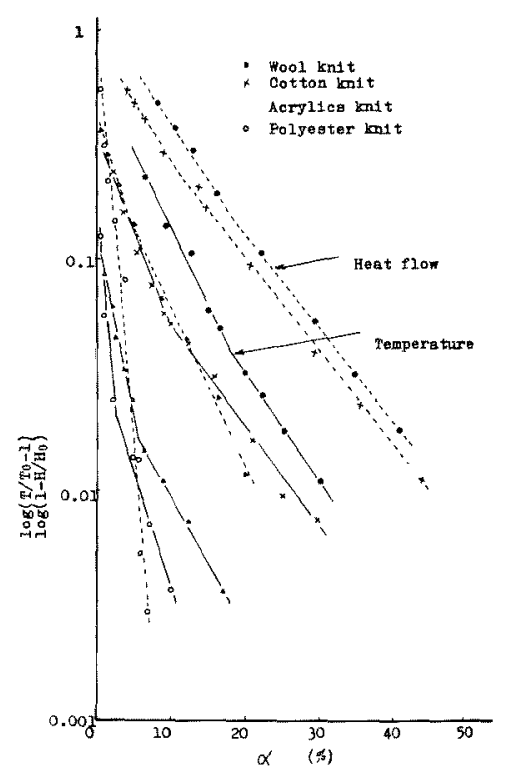

Fig. 7 Relation between $\log \left(T / T_{0}-1\right)$ and $\log \left(1-H / H_{0}\right)$ and $\alpha$.

\section{2 官能試験の結果}

\section{A. 水分率を規定した布の堨合}

図 8 亿湿感お上び密着感の官能検查による評定結果を 図示した。温冷感求よび快商感の評定結果もよく似た慎 向を示した。ポリエステル試料の場合図 8 亿よ机保水分 率がもっとも低い段階で湿感ないしは密着感を感ずるよ うになり羊毛試料ではをの逆の性質を示している。

一方アアクリル試料や木綿試料ではその中間的な性質 走示している。その場合，水分率が低いととろではアク リルの方が湿感や密着感を感じやすく，水分率が高いと ころでは木綿の方がそれを感じすすくなる傾向にある。 つぎに図8(a)の湿感について，官能検査の情報をす

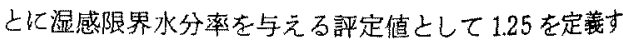
ると，湿感限界水分率 $\alpha_{\mathrm{s}_{1}}(\%)$ は羊毛試料では $16 \%$ ，末 綿試料では $11 \%$ ，アクリル試料で $5 \%$ ，ポリエステル試 

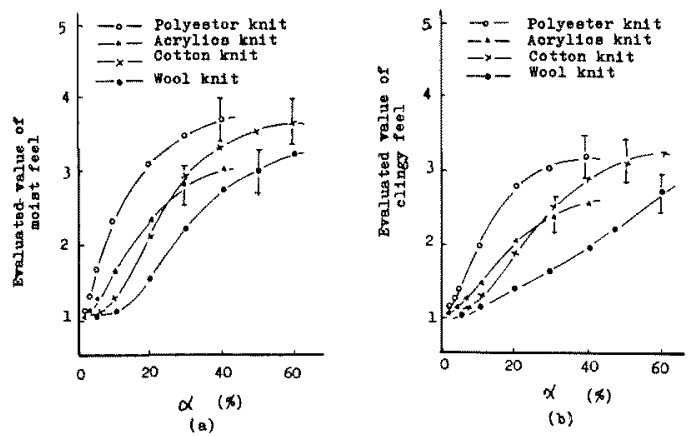

Fig. 8 Relation between moist feel and clingy feel of fabric and water content $\alpha$.

(a) Moist feel, (b) Clingy feel.

料で3\%程度の值を示した。

\section{B．乾嬠過程にある布の婸合}

乾燥過程にある布について，湿感の官能検查を丰施し， 湿感限界水分率 $\alpha_{S_{2}}(\%)$ を求めた。䊅果はほぼ羊毛試料 で $13 \%$ ，木綿試料で $9 \%$ ，アクリ儿試料で $22 \%$ ，ポリエ ステル試料で $1.5 \%$ の檤を得た。

\section{4. 考察}

以上の結果を図 9，図10に対比して示した。すなわ ち、図 9 には密着力の限界水分率之潞度扣上び熱流量の 第2 限界水分率との関係を対比し，図10 亿は官能試騷 および文献による湿感限界水分率上各物理誁験に上る限 界水尔率扰よじ第 2 限界水分率上の関係を対比して示し た。

それらの結果は各測定值がかなり類似した対応関係に

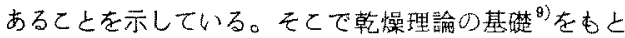

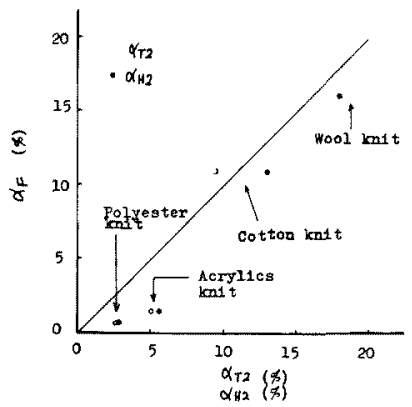

Fig. 9 Relation between the critical water content of clingy force gave from the measurement of the sliding resistance of water absorbed fabric $\left(\alpha_{F}\right)$ and the second critical water content of temperature or heat flow in the period of drying of wet fabric $\left(\alpha_{T_{2}}, \alpha_{H_{2}}\right)$.

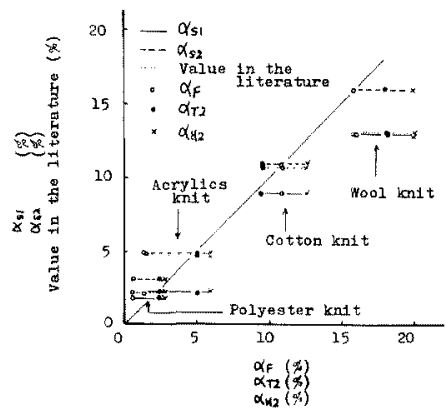

Fig. 10 Relation between the critical water content of moist feel by the sensary test $\left(\alpha_{S_{1}}, \alpha_{S_{2}}\right.$ or value in literature $)$ and the critical water content of temperature or heat flow by the physical test $\left(\alpha_{F}, \alpha_{T_{3}}\right.$ or $\alpha_{H_{2}}$ ).

に湿感限界水分率の布中の水往機構を考えて見る上，乙 の機構は布中に液状水の拡散移動が存在するか，しない 加，い心かえれば気状水の拡散移動に波状水の应散移動 がともない始力る限界の水分状態にあるもの上推察され b。

また，乾燥過程に括ける限界水争率が，四8 の評定值 3在示寸水分率と比較的よく対応しているとと加ら布の 水分率が減率乾燥期間と恒率乾燥期間の境目に相当する 限界水分率のところでは，つまり布中の水分機構が夜状 水のみの水分移動に移るととろでは湿感に好れ感が付加 される状沉にあるものと推察される。

\section{5. まとめ}

布の湿感ないしは密着感，特に湿感险界水分率の物理

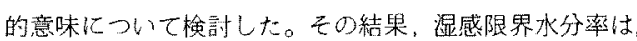
布の密着力が顕著な增大を示すととろの水分率之湿潤布 の乾燥過程に招ける第 2 限界水分率とに上く対応し，末 た，有の水分率が乾燥過程の限界水分率近くになると湿 感に好れ感が付加されるととの結果を得た。なお，現在 接触面積との関係についても検討中である。

\section{付 録}

いま付図に执いて布が円筒上の接触点Aから任意の角 度 $\theta$ だけ離れた C点で，微小中心角度 $d \theta$ に対する微小 布の試料部分CDEFについて，力の釣合い存考える。 そして，この部分のC F 端で右に㗢く力を $R$ とすると， $\mathrm{DE}$ 端で㗢く力は $R+d R$ となる。 $d R$ は微小䚮試料の自 重に上る法線力摩摖条件加低荷重の大力，試料の自重 を補正して考える) と $F$ (被接触面の半径 $r$ の位置で作用 する上する)上R上による摩摖力上により次式の上うに 近倾さ扎る(Eulerのベルトの理論による)。 


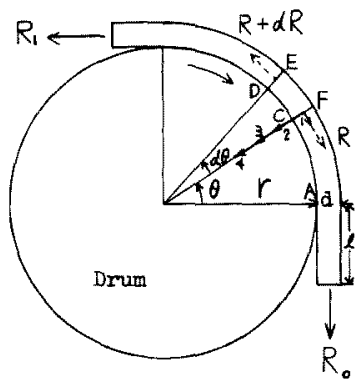

Fig. 11 The equation of the sliding resistance of water absorbed fabric on the basis of Euler's belt theory, which was modified to include an adhesion term.

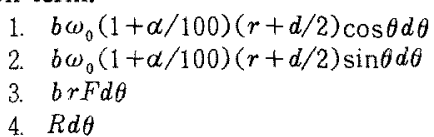

$$
\begin{aligned}
d R= & b \omega_{0}(1+\alpha / 100)(r+d / 2) \cos \theta d \theta \\
& +\mu\left(b \omega_{0}(1+\alpha / 100)(r+d / 2) \sin \theta d \theta\right. \\
& +b r F d \theta+R d \theta
\end{aligned}
$$

(5) 式を解くと

$R=b \omega_{0}(1+\alpha / 100)(r+d / 2)\left\{\left(1-\mu^{2}\right) \sin \theta-2 \mu \cos \theta\right\}$

$/\left(1+\mu^{2}\right)-b r F+c e^{\mu \theta}$ がえられる。ここで，c：皘分定数である。次に(6)式 を初期条件， $\theta=0$ ○上さ $R=R_{0}$ で解くと $R=b \omega_{0}(1+\alpha / 100)(r+d / 2)\left\{\left(1-\mu^{2}\right) \sin \theta\right.$ $-2 \mu \cos \theta\} /\left(1+\mu^{2}\right)-b r F$ $+\left\{R_{0}+2 b \omega_{0}(1+\alpha / 100)(r+d / 2) \mu /\left(1+\mu^{2}\right)\right.$ $+b r F\} e^{\mu \theta \theta}$

がえられる。黑験条件， $\theta=\pi / 2(\mathrm{rad}) を(7)$ 式化代入す ると，すべり抵挖 $R(\mathrm{~g})$ は (4) 式で示される。

\section{文献}

1) 福井；関口；繊学誌，36，P-313(1980)

西海；繊学誌，31，P-63(1975)

2) 久山; 海瀻技文集，p.11(1979)

3） L.フォート、N.R.S.ホリーズ; 被服機構学, 光生 館 (1972)

4）たと元ば，我妻；「緎維の物性之紡績理論」， p.22， 非壳品 (1960)

5) 兽田; 「摩摖の話」，p.79，岩波新畫 (1979)

6) 松并，近藤，荒井，山本；緎学誌，37，P-313(1980)

7) 石川，西尾；絨消誌，22，40(1981)

8) R. E. Belin, A. F. Morrey; J. Text. Inst., 65, p. 187 (1974)

9) 桐栄; 繊維工学, 19, p.655(1966) 